\title{
BIOFILTER AEROB MEDIA KALDNESS DALAM MENURUNKAN KADAR BOD, COD DAN TSS LIMBAH CAIR RUMAH MAKAN
}

Yuli Sifaul U, Iva Rustanti Eri W, Pratiwi Hermiyanti

Jurusan Kesehatan Lingkungan Poltekkes Kemenkes Surabaya Email: syifa.yuli96@gmail.com

\begin{abstract}
ABSTRAK
Limbah cair rumah makan seafood yang dijadikan lokasi penelitian ini tidak melakukan proses pengolahan limbah terlebih dahulu sebelum dibuang ke badan air. Penelitian ini bertujuan untuk mengurangi BOD, COD, dan TSS di air limbah restoran dengan mengolah biofilter aerobik menggunakan media kaldness.

Jenis penelitian ini adalah eksperimen dengan desain penelitian pretest-posttest. Waktu kontak yang dilakukan selama 1 bulan dengan pengambilan sampel sebanyak 12 kali. Data dianalisa secara deskriptif yaitu membandingkan dengan Pergub Jatim no 72 tahun 2013 dan dilakukan penghitungan efisiensi penurunannya.

Hasil pemeriksaan kadar BOD, COD dan TSS sebelum pengobatan dengan media BOD kaldness adalah $333.822 \mathrm{mg} / \mathrm{L}$, COD $575.535 \mathrm{mg} / \mathrm{L}$ dan TSS $580.13 \mathrm{mg} / \mathrm{L}$. Setelah pengolahan dengan media kaldness kadar BOD menjadi $580 \mathrm{mg} / \mathrm{L}$, COD $1019 \mathrm{mg} / \mathrm{L}$, dan TSS $430 \mathrm{mg} / \mathrm{L}$.

Kesimpulan dari penelitian ini adalah biofilter media Kaldnes sangat efisien dalam menurunkan kandungan BOD sebesar 99,98\%, COD sebesar 99,82\% dan TSS sebesar 99, $92 \%$ dalam limbah rumah makan seafood.
\end{abstract}

Kata kunci: Air Limbah Restoran, BOD, COD dan TSS

\section{PENDAHULUAN}

Rumah makan yang menjadi tempat pengolah makanan, selain limbah padat juga menghasilkan limbah cair yang menyebabkan pencemaran lingkungan di sekitarnya. Limbah cair rumah makan adalah limbah yang berasal dari kegiatan operasional suatu rumah makan mulai dari proses menyiapkan bahan- bahan makan yang meliputi pemilahan dan pencucian bahan baku, proses pengolahan makan, serta proses pembersihan peralatan makan. $\mathrm{Di}$ samping limbah yang dihasilkan proses pengolahan makanan, limbah berasal dari toilet (kamar mandi dan jamban) berupa, karbohidrat, protein, lemak dan minyak.

Limbah cair rumah makan bersifat organik maupun anorganik, sehingga diperlukan pengolahan terlebih dahulu sebelum dikeluarkan ke saluran drainase kota sesuai baku mutu Pergub Jatim No 72 Tahun 2013 tentang Baku Mutu Air Limbah bagi Industri dan / atau Kegiatan Usaha lainnya. $\mathrm{Di}$ dalam proses pengolahan air limbah khususnya yang mengandung polutan senyawa organik, teknologi yang digunakan sebagian besar menggunakan aktifitas mikroorganisme untuk menguraikan senyawa polutan organik tersebut yang disebut dengan "Proses Biologis". Proses pengolahan air limbah secara biologis tersebut dapat dilakukan pada kondisi aerobik (dengan udara).

Biofilter merupakan suatu reaktor biologis (fixed-film) menggunakan persiapan berupa kerikil, plastik atau bahan padat lainnya dimana limbah cair dilewatkan melintasinya seara kontinu. Adanya bahan isian padat menyebabkan mikroorganisme yang terlibat tumbuh dan melekat atau membentuk lapisan tipis pada permukaan media tersebut (MetCalf dan Eddy, 2003).

Keunggulan dalam biofilter Aerob adalah pengoperasianya mudah, lumpur yang dihasilkan sedikit, dapat digunakan untuk pengolahan limbah dengan konsentrasi tinggi maupun rendah, dan pengaruh perubahan suhu terhadap efisiensi pengolahan kecil.

Penggunaan kaldness sebagai media biofilter diharapkan mampu menurunkan parameter kimia yang terdapat pada 
limbah rumah makan. Tujuan dari penelitian ini untuk mengukur parameter BOD, COD dan TSS sebelum dan sesudah melalui perlakuan dengan media kaldness dan membandingkan dengan Baku Mutu yang berlaku.

\section{METODE PENELITIAN}

Penelitian ini termasuk penelitian eksperimen murni dan menggunakan desain penelitian "Pretest-Posttest". Rancangan peneliti ini dilakukan observasi (pengukuran yang berulang - ulang), sebelum dan sesudah perlakuan eksperimen.

Variabel terikatnya dalam penelitian ini adalah kadar BOD, COD dan TSS. Variabel bebasnya adalah biofilter aerob dan luas permukaan media. Teknik pengumpulan data berdasarkan hasil pemeriksaan laboratorium mengenai kadar BOD, COD dan TSS dalam pengolahan limbah cair rumah makan dengan menggunakan biofilter aerob. Analisis data dalam penelitian ini menggunakan uji anova satu arah.

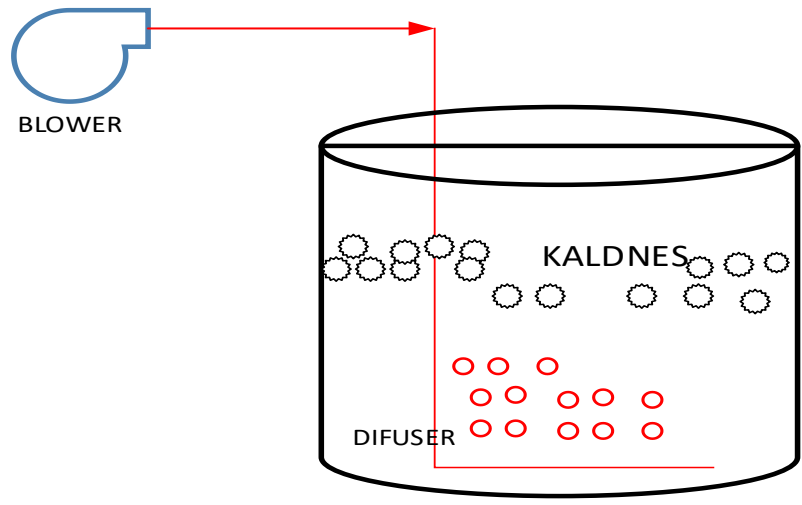

REAKTOR BIOFILTER

Gambar 1. Desain Gambar Alat

Reaktor Biofilter

HASIL DAN PEMBAHASAN

Tabel 1

HASIL PEMERIKSAAN KADAR BOD, COD dan TSS MENGGUNAKAN MEDIA KALDNESS

\begin{tabular}{ccc}
\hline Parameter & Sebelum pengolahan & Setelah pengolahan \\
\hline BOD & $333.822 \mathrm{mg} / \mathrm{L}$ & $580 \mathrm{mg} / \mathrm{L}$ \\
\hline COD & $575.535 \mathrm{mg} / \mathrm{L}$ & $1019 \mathrm{mg} / \mathrm{L}$ \\
\hline TSS & $580.136 \mathrm{mg} / \mathrm{L}$ & $430 \mathrm{mg} / \mathrm{L}$ \\
\hline
\end{tabular}

Sesuai dengan tabel di atas, terjadi penurunan kadar BOD, COD dan TSS secara signifikan setelah limbah rumah makan seafood melalui pengolahan menggunakan media kaldness. Hal ini terjadi karena adanya penambahan oksigen yang dialirkan blower ke dalam reactor berisi kaldness, sehingga mikroorganisme yang melekat pada media dapat menurunkan kadar BOD, COD dan TSS pada limbah. Secara garis besar, penurunan kadar BOD melalui pengolahan menggunakan media kaldness selama 528 jam dapat ditunjukkan pada gambar di bawah ini 


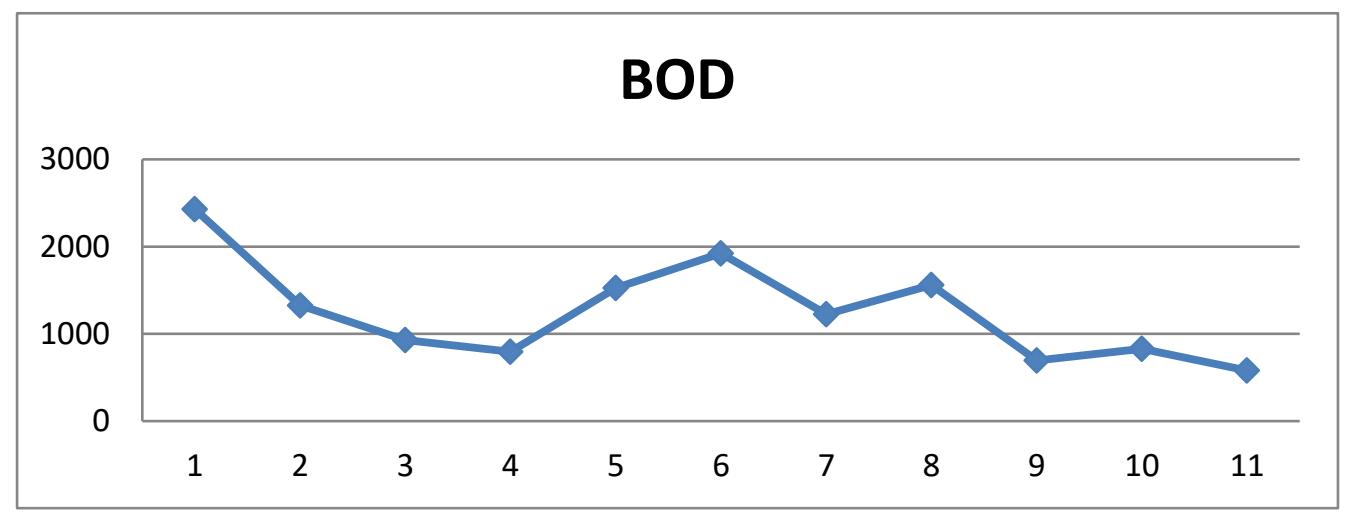

Gambar 1. Penurunan Hasil Pemeriksaan Kadar BOD

Kadar BOD sesuai Peraturan Gubernur Jatim No 72 Tahun 2013 tentang Baku Mutu Air Limbah Domestik yaitu 30 $\mathrm{mg} /$ liter. Sesuai gambar 1, terjadi penurunan kadar BOD secara signifikan, namun masih belum sesuai persyaratan. Tingginya kadar BOD yang terdapat pada limbah rumah makan seafood masih diperlukan pengolahan lebih lanjut agar kualitas limbah yang dilepas ke lingkungan tidak menimbulkan pencemaran. Pencemaran selain pada badan air juga memungkinkan mencemari air tanah di sekitar badan air. Hal ini sesuai dengan pernyataan Kusnoputranto (1983) bahwa limbah dapat mencemari air tanah di sekitar resapan kakus di Kebayoran Lama Jakarta Selatan.

Biofilter media kaldness mampu menurunkan kadar BOD dalam limbah cair rumah makan seafood, hal ini sesuai dengan penelitian Anisa (2017) bahwa kandungan BOD dan nirogen limbah domestik dapat diturunkan menggunakan metode MBBR dengan media kaldness.

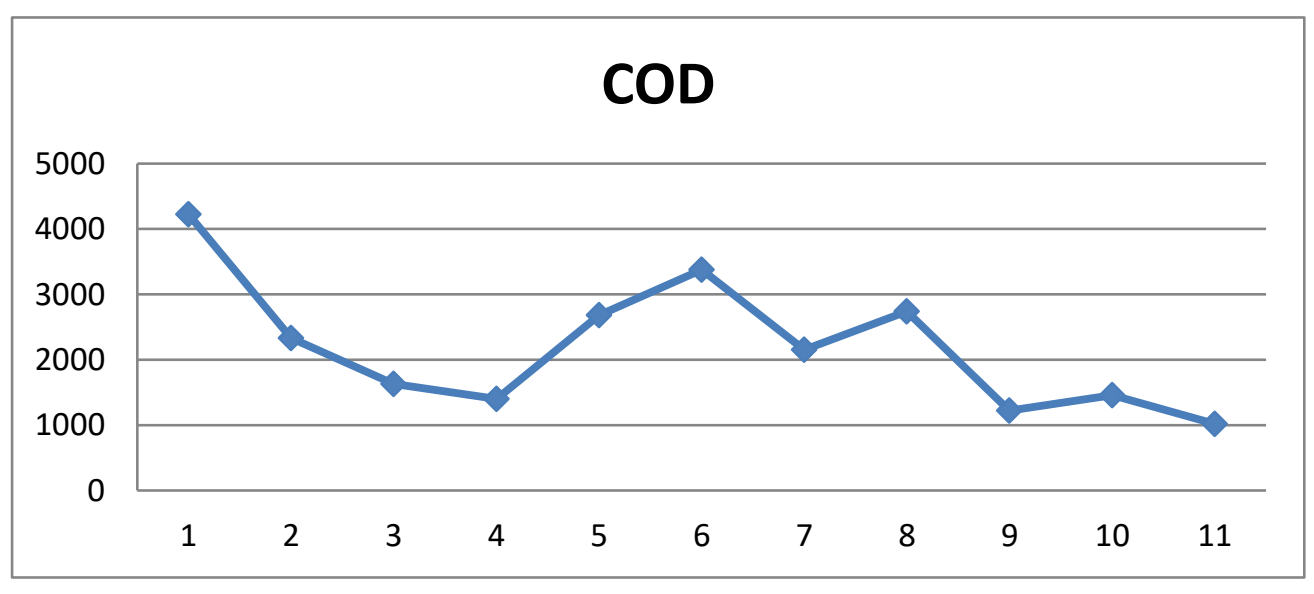

Gambar 2. Penurunan Hasil Pemeriksaan Kadar COD

Kadar COD menurut Peraturan Gubernur Jatim No 72 Tahun 2013 tentang Baku Mutu Air Limbah Domestik yaitu 50 $\mathrm{mg} /$ liter. Berdasarkan gambar 2 dapat dijelaskan bahwa kadar COD setelah melalui pengolahan menggunakan biofilter aerob menggunakan media kaldness mengalami penurunan, namun masih belum memenuhi syarat Pergub Jatim. Hal ini diperkuat dengan tabel 1 yang menunjukkan terjadi penurunan COD dari $575.535 \mathrm{mg} / \mathrm{L}$ menjadi 1019 $\mathrm{mg} / \mathrm{L}$. Berdasarkan penjelasan tersebut, masih diperlukan pengolahan lanjutan agar kadar COD dalam limbah rumah makan dapat mengalami penurunan. 


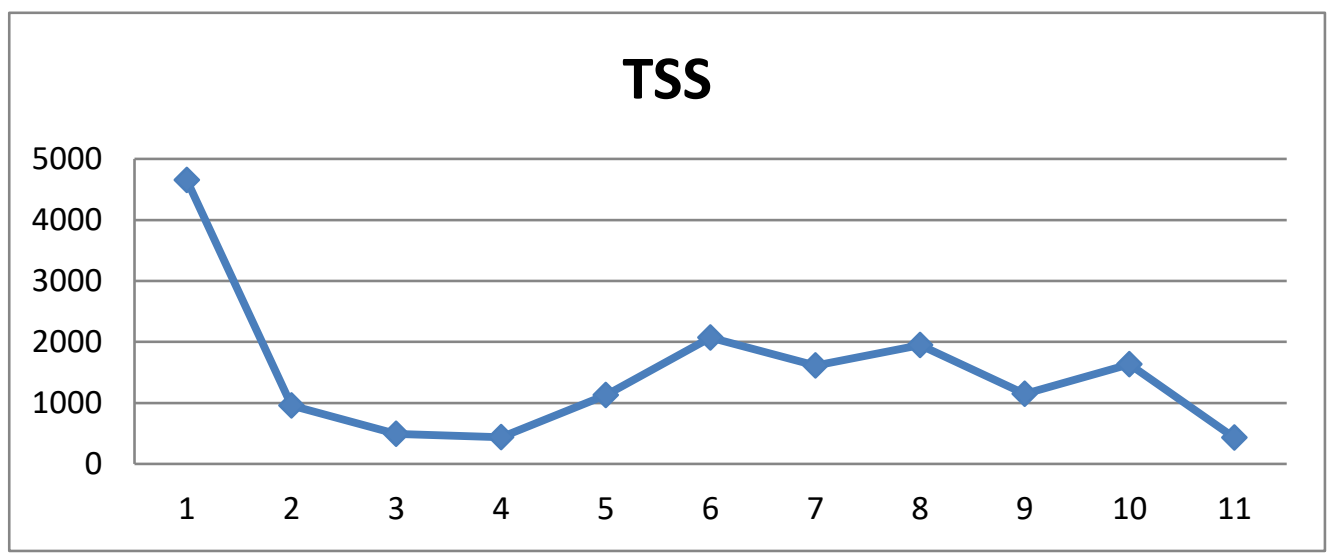

Gambar 3. Penurunan Hasil Pemeriksaan Kadar TSS

Kadar TSS menurut Peraturan Gubernur Jatim No 72 Tahun 2013 tentang Baku Mutu Air Limbah Domestik yaitu 50 $\mathrm{mg} /$ liter. Berdasarkan gambar 3 dapat dijelaskan bahwa kadar TSS setelah melalui pengolahan menggunakan biofilter aerob menggunakan media kaldness mengalami penurunan, namun masih belum memenuhi syarat Pergub Jatim. Hal ini diperkuat dengan tabel 1 yang menunjukkan terjadi penurunan TSS dari $580.136 \mathrm{mg} / \mathrm{L}$ menjadi $430 \mathrm{mg} / \mathrm{L}$. Berdasarkan penjelasan tersebut, masih diperlukan pengolahan lanjutan agar kadar TSS dalam limbah rumah makan dapat mengalami penurunan. Atau diperlukan pra pengolahan sebelum limbah dimasukkan dalam realtor biofilter aerob media kaldness. Pra pengolahan yang dapat dilakukan adalah proses sedimentasi. Setelah proses sedimentasi, kadar TSS dapat diturunkan menggunakan metode biofilter dengan melewatkan limbah pada media tertentu yang ditumbuhi mikroorganisme dengan system aerobic (Purwanto, 2011).

Berdasarkan hasil yang diperoleh, efisiensi penurunan BOD, COD dan TSS secara berturut-turut selama 1 bulan (12 sampel) didapatkan hasil yang paling signifikan pada sampel ke -12 (528 jam) yaitu 99,98\%, 99,82\%, 99,92\%.

\section{KESIMPULAN}

Biofilter aerob media Kaldness sebagai pengolahan limbah cair rumah makan dapat menurunkan kadar BOD, COD dan TSS. Jika dibandingkan dengan
Peraturan Gubernur Jatim no 72 tahun 2013 tentang Baku Mutu Air Limbah Domestik, kadar BOD, COD dan TSS limbah rumah makan masih belum sesuai baku mutu yang dipersyaratkan.

\section{SARAN}

Pihak rumah makan dapat melakukan pra pengolahan limbah cair melalui proses sedimentasi sebelum limbah diolah menggunakan biofilter media kaldness.

\section{DAFTAR PUSTAKA}

Anisa,Ana dan Welly

Herumurti.2017.Pengolahan Limbah Domestik menggunakan Moving Bed Biofilm Reactor (MBBR) dengan proses aerobikanoksik untuk menurunkan nitrogen.ISSN.Jurnal Teknik ITS.06.362-365.

Kusnoputranto, H., I Made Jaya, 1983. Studi Pencemaran Bakteriologi Kakus Cubluk Terhadap Air Tanah Di Wilayah Kecamatan Kebayoran Lama, Jakarta Selatan, Fakultas Kesehatan Masyarakat UI.

MetCalf and Eddy, 2003. Wastewater Engineering. Mc Graw Hill.

Purwanto, Didik, Sugeng 2011. Pengolahan Limbah Cair Sistem An-Aerobik Aerobik Biofilter. Surabaya. Perc Duatujuh.14.

Purwanto, Didik, Sugeng 2008. Pengolahan Limbah Cair.Surabaya, PercDuatujuh :227 